\title{
The Effect of Non-Performing Loans on Profitability in Banking Sector in Indonesia
}

\author{
Catur Rahayu Martiningtiyas*, Dewi Tirtarini Nitinegeri \\ Faculty of Economics and Business \\ Universitas Trisakti \\ Jakarta, Indonesia \\ *catur.tinuk@gmail.com
}

\begin{abstract}
The objective of this study is to analyze the effect of non-performing loans on bank profitability. The dependent variable in this study is profitability and the independent variable is non-performing loans by using control variables are liquidity ratio, capital adequacy ratio, gross domestic product and size. This study uses 26 conventional banks that are listed on Indonesian Stock Exchange in the period between 2009-2017 by using purposive sampling. The results of this study show that non-performing loans variable has a significant negative influence on profitability bank. Liquidity ratio and gross domestic product have significant positive influence on profitability bank whereas capital adequacy ratio does not have significant influence on profitability bank. Implications: For conventional banking firms they are expected to do monitoring so that the level of non-performing loans is low, monitoring the level of liquidity ratio, are also contributing in increasing the growth of gross domestic product to increase profitability bank.
\end{abstract}

Keywords-capital adequacy ratio, gross domestic product, liquidity ratio, non-performing loans, bank size, profitability

\section{INTRODUCTION}

The financial sector in Indonesia is currently dominated by the banking sector, from data showing that total assets in banking sector in 2015 reached $80 \%$ of all assets in the financial sector [1]. Financial data shows that the banking sector plays a role in the economy in Indonesia. The role of banks in the country's economy can be judged by its improved performance. Mbella and Magloire explain that good bank performance will attract investors to invest their capital in banks which have implications specifically for bank growth and generally affect economic growth [2], otherwise bad bank performance will result in bank failures in conducting their business and impact during a country's economic growth crisis. It related to financially constrained on investment, therefore investment decision making is an important thing to do [3].

Banking sector performance is usually reflected in an increase in the profitability ratio of a company which shows that the ability of banks to obtain very high profits [4]. The level of bank profitability can be measured by return on assets (ROA) which illustrates the power of banks to generate profits by utilizing assets effectively and efficiently [5].

Kingu et al. explains that one of the factors that most strongly influences a bank's profitability is non-performing loans, that is, a ratio that measures a bank's credit risk [5]. Nonperforming loans generally occur because the debtor cannot pay the interest and principal of the loan so that the profit of a bank is reduced [6]. This will affect the level of profitability, if the non-performing loans of a bank is higher then there will be a decrease in the level of income, which means there is a negative influence between non-performing loans on profitability [7]. Other factors that can have an impact on the level of bank profitability aside from non-performing loans are the level of liquidity, capital adequacy ratio, gross domestic product (GDP) and bank size (BS).

Liquidity ratio is a ratio that measures a company's ability to meet short-term obligations when due [2]. The higher liquidity ratio shows the amount of deposit funds disbursed for lending, but not followed by repayment of credit funds by debtors that cause problem loans and result in a decrease in profitability of a bank [8]. This indicates a negative influence between liquidity ratio and profitability of a bank [5].

Capital adequacy ratio is a standard set by Bank Indonesia (BI) to measure the capital adequacy ratio of a bank. BI stipulates that bank sector must have a capital adequacy ratio of not less than $8 \%$ which shows the bank is in a healthy position [9]. A high capital adequacy ratio will reduce the bank's dependence on using external funds to bear credit risk thereby increasing bank profitability [10,11]. Therefore, the capital adequacy ratio has a significant positive effect on the bank profitability [12].

The gross domestic product (GDP) growth rate is an external factor in a country's economic activities that affects the profitability of a bank [13]. High GDP growth will increase the demand for loans by the public which has an impact on increasing the profitability of a bank [14]. Thus, there is a 
significant positive influence between GDP and bank profitability [15]. In addition, Menicucci and Paolucci stated that bank size has a positively affects and significantly influences bank profitability [12].

\section{LITERATURE REVIEW}

\section{A. Profitability}

Profitability is the company's strength to generate profits every year which shows the company's success in running its business [12]. Profitability is also interpreted as an assessment of the company's ability to obtain profits by comparing the profits generated and costs incurred by the company in a certain period [16]. The Ikatan Bankir Indonesia [17] explains that banks with good earnings quality means that banks have the strength and ability to support capital, asset growth and operational management. Meanwhile, banks with poor profit quality indicate the inability of banks to finance customers' credit needs.

\section{B. Non-Performing Loans}

Non-performing loans is a loan fund which is blocked by the debtor's return [18]. Non-performing loans are defined as loans that the debtor cannot pay or fulfill obligations according to a credit agreement for ninety days or more at maturity [19]. Non-performing loans are a measure to assess the credit quality of a bank [17]. The higher quality of loans given by banks can reduce the risk of the possibility of bad credit [4]. Nonperforming loans can be calculate using the ratio of nonperforming loans to the number of loans [18]

\section{Liquidity Ratio}

Liquidity is the ability of banks to meet short-term obligations when due [15]. Fahmi [20] describes liquidity as the ability of banks to provide savings when withdrawals by customers, meet funding requests for credit, and control the operational conditions of a bank. Liquidity ratios are used to measure the liquidity position of a bank which is calculated by comparing net loans and total deposits, if the liquidity ratio is high then the liquidity risk will increase resulting in a bank's financial difficulties [5]. Liquidity ratio is calculated by comparing the ratio of credit and deposits, if the ratio is not managed properly will have an impact on the failure of a bank in running its business [10].

\section{Capital Adequacy Ratio}

Capital adequacy ratio is the ratio of capital adequacy owned by banks to support credit activities [4]. Ozili [11] defines the Capital Adequacy Ratio as the capital ratio used to overcome credit risk. Fahmi [20] explains the capital adequacy ratio as a ratio to assess a bank's capital ability to fund all it's business activities to cover credit activities that contain risks. Capital adequacy ratio serves to protect customers from potential unexpected losses and as a reserve when a crisis occurs in a bank. Bank Indonesia (BI) regulations set a capital adequacy ratio standard for a healthy bank, that is, no less than $8 \%$ [9].

\section{E. Gross Domestic Product (GDP)}

Gross domestic product (GDP) is a macroeconomic factor of a country that is in the bank's external environment and indirectly influences the activities of a bank [15]. Mankiw [21] discusses GDP as a measurement in a country's economy to calculate total community income and total expenditure on goods and services produced. GDP can be calculated and obtained from annual GDP growth rates [5]. Ally [10] argues that a country's GDP growth can affect the increase in demand for loans by the public and supply of deposits by banks.

\section{F. Bank Size (BS)}

Menicucci and Paolucci [12] stated that bank size positively and significantly affects bank profitability, this shows the size of a bank is a measure of the amount of investment made by banks to increase bank profitability. Roman and Şargu state that the size of the bank's company uses ln total assets [13].

\section{METHODS}

This research uses hypothesis testing to see the effect of non-performing loans on bank profitability. Based on the type of data, this study is included in the panel data because it examines several conventional banks in Indonesia with several periods of research. The object of research used in this study uses conventional bank data listed on the Indonesia Stock Exchange (IDX) from 2009 to 2017 with observation data of 234.

Regression Analysis:

$$
\begin{gathered}
\mathrm{ROA}=\alpha+\beta_{1} \mathrm{NPL}+\gamma_{2} \mathrm{LQDT}+\gamma_{3} \mathrm{SLVT}+\gamma_{4} \mathrm{GDPGR}+ \\
\gamma_{5} \mathrm{SIZE}+\varepsilon
\end{gathered}
$$

$$
\begin{aligned}
& \text { ROA }=\text { Return on Asset } \\
& \alpha \quad=\text { Constanta } \\
& \beta_{1} \quad=\text { Coeff of Non-performing Loans } \\
& \gamma_{2} \quad=\text { Coeff of Liquidity Ratio } \\
& \gamma_{3} \quad=\text { Coeff of Capital Adequacy ratio } \\
& \gamma_{4} \quad=\text { Coeff of Gross Domestic Product }
\end{aligned}
$$

$\mathrm{NPL}=$ Non-performing Loans

$\begin{array}{ll}\text { LQDT } & =\text { Liquidity Ratio } \\ \text { SLVT } & =\text { Capital Adequacy Ratio } \\ \text { GDPGR } & =\text { Gross Domestic Product Growth Rate } \\ \mathrm{e} \quad=\text { Residual (Error) }\end{array}$


TABLE I. VARIABLE AND MEASUREMENTS

\begin{tabular}{|l|l|l|l|}
\hline \multicolumn{1}{|c|}{ Variables } & Measurements & \multicolumn{1}{|c|}{$\begin{array}{c}\text { Expected } \\
\text { Sign }\end{array}$} & Literature \\
\hline $\begin{array}{l}\text { Dependent Variable } \\
\text { (ROA) }\end{array}$ & $\begin{array}{l}\text { Net Profits / } \\
\text { Total Assets }\end{array}$ & [5] \\
\hline $\begin{array}{l}\text { Independent } \\
\text { Variables }\end{array}$ & $\begin{array}{l}\text { Total Non- } \\
\text { performing Loans } \\
\text { / Total Loans }\end{array}$ & $(-)$ & {$[18]$} \\
\hline $\begin{array}{l}\text { Loans } \\
\text { Control Variables }\end{array}$ & $\begin{array}{l}\text { Net Loans / Total } \\
\text { Deposits }\end{array}$ & $(-)$ & {$[5],[13]$} \\
\hline Liquidity Ratio & $\begin{array}{l}\text { Equity / Total } \\
\text { Assets }\end{array}$ & $(+)$ & {$[5]$} \\
\hline $\begin{array}{l}\text { Capital Adequacy } \\
\text { Ratio Domestic }\end{array}$ & $\begin{array}{l}\text { Year - on - Year } \\
\text { GDP Growth } \\
\text { Rate }\end{array}$ & $(+)$ & {$[5]$} \\
\hline $\begin{array}{l}\text { Gross Total Asset } \\
\text { Product (GDP) }\end{array}$ & $(+)$ & {$[13]$} \\
\hline Bank Size & \multicolumn{1}{|c|}{} & \\
\hline
\end{tabular}

\section{RESULTS AND DISCUSSION}

The object of research used is conventional banking companies listed on the Indonesia Stock Exchange with a sample of 26 banks. This study uses secondary data, namely, financial statements recorded during the last nine years of the period 2009 to 2017. The number of observational data is 234 observations.

TABLE II.

DESCRIPTIVE STATISTIC

\begin{tabular}{|l|c|c|c|c|c|}
\hline Variables & Obs & Mean & $\begin{array}{c}\text { Std. } \\
\text { Deviasi }\end{array}$ & Minimum & $\begin{array}{c}\text { Maximu } \\
\text { m }\end{array}$ \\
\hline ROA (\%) & 234 & 0.011251 & 0.014314 & -0.117277 & 0.034102 \\
\hline NPL (\%) & 234 & 0.026533 & 0.018559 & 0.002144 & 0.158211 \\
\hline $\begin{array}{l}\text { LQDT } \\
(\%)\end{array}$ & 234 & 0.871836 & 0.256176 & 0.357370 & 2.183570 \\
\hline SLVT (\%) & 234 & 0.131202 & 0.100762 & 0.060168 & 1.542252 \\
\hline $\begin{array}{l}\text { GDPGR } \\
(\%)\end{array}$ & 234 & 0.054367 & 0.006293 & 0.046300 & 0.064900 \\
\hline
\end{tabular}

TABLE III. TEST RESUlt (HIPOTHESIS TEST)

\begin{tabular}{|l|l|l|}
\hline Variable & \multicolumn{1}{|c|}{ Coefficient } & \multicolumn{1}{c|}{ Prob. } \\
\hline NPL & -0.475762 & $0.0000^{*}$ \\
\hline LQDT & 0.001781 & 0.5950 \\
\hline SLVT & -0.005254 & 0.3638 \\
\hline GDPGR & 0.230370 & $0.0102^{*}$ \\
\hline BS & -0.002242 & $0.0001^{*}$ \\
\hline
\end{tabular}

*Significant on alpha $0.05(5 \%)$

The results showed that non performing loans had a significant negative impact on profitability. This study is in accordance with previous research conducted by Roman and Şargu [13] which shows that there is a significant negative effect between non-performing loans and profitability. This research is also supported by Hallunovi and Berdo [7] which discussed that non performing had a negative impact on profitability.
Liquidity ratio also has a significant positive effect on profitability. This research is supported by research Juwita et al. [22] which explains that the high liquidity ratio will affect profitability because the more customers deposit funds provided for loans will increase bank profits derived from credit interest income. Ally [10] also proved in his research that liquidity ratio has a significant positive effect on profitability where the high liquidity ratio of a company indicates that available investment funds will increase profitability. The results of this study are strengthened by the research of Haidary and Abbey [15] which shows the company's liquidity ratio has a positive influence to profitability.

Capital adequacy ratio does not have a significant effect on profitability. This research is in line with research conducted by Kusmayadi [23] which proves that there is no influence between the capital adequacy ratio to profitability, which means the size of the capital adequacy ratio of a bank cannot contribute to increasing bank profitability because of the provisions set by Bank Indonesia (BI) many banks must have a capital adequacy ratio of $8 \%$ which shows the bank is in a healthy condition. Ndoka and Islami [24] also support the results of this study which explain the absence of influence between the capital adequacy ratio and profitability.

Gross domestic product (GDP) has a significant positive influence on profitability. The results of this study are in line with research from Bilal et al. [25] who found that GDP had a significant positive effect on a bank's profitability. Samad [14] explained that increasing economic growth was able to increase people's desire to save and increase demand for a loan by the community so that a lot of credit loan funds that banks had to give to the community. The more credit loans provided by banks, this increases profits which results in a high level of profitability of a bank. Haidary and Abbey [15] also support this study which shows a positive influence between GDP and profitability.

Bank Size has a positive and significant effect on profitability. The results of this study are supported by research conducted by Roman and Şargu [13].

\section{CONCLUSION}

To increase the profitability of a bank, managers should pay attention to non-performing loans, liquidity ratio, gross domestic product (GDP) and bank size. In maintaining nonperforming loans so as not to increase the bank must increase monitoring in it's management by paying attention to the analysis of lending such as procedures for granting loans, examining data information about debtors, controlling the duration of lending and repayment of loans so as to avoid the existence of problem loans or bad loans. While the liquidity ratio, banks must increase monitoring of each customer's funds both deposit funds received and credit funds provided to debtors. In addition, an increase in GDP of a country must be supported by an increase in optimal lending to entrepreneurs in Indonesia so that it is expected to have an impact on increasing bank profitability with an increase in bank investment. 


\section{REFERENCES}

[1] Y.Y. Prahadi, "Sistem Keuangan RI Didominasi Perbankan," [Online]. Retrieved from: https://swa.co.id/swa/trends/management/sistemkeuangan-ri-perbankan-masih-mendominasi. (Diakses 5 Oktober 2018), 2015.

[2] M.E. Mbella and A.A. Magloire, "The Effect of Bank Specific Factors on the Performance of Afriland First Bank in Cameroon," Journal of Business \& Financial Affairs, Vol. 06, No. 04, pp. 130-137, 2017.

[3] W.R. Sari and F.M. Leon, "The influence of investment-cash flow sensitivity and financially constrained on investment," Jurnal Keuangan dan Perbankan, Vol. 24, No. 1, pp. 30-39. 2020.

[4] Kasmir, Manajemen Perbankan. Jakarta: RajaGrafindo Persada, 2017.

[5] P.S. Kingu, S. Macha and R. Gwahula, "Impact of Non-Performing Loans on Bank's Profitability: Empirical Evidence from Commercial Banks in Tanzania," International Journal of Scientific Research and Management, Vol. 6, No. 01, pp. 71-78. 2018.

[6] E. Laryea, M. Ntow-Gyamfi and A.A. Alu, "Nonperforming loans and bank profitability: evidence from an emerging market," African Journal of Economic and Management Studies, Vol. 7, No. 4, pp. 462-481, 2016.

[7] A. Hallunovi and M. Berdo, "The Relationship between Risk Management and Profitability of Commercial Banks in Albania," Asian Themes in Social Sciences Research, Vol. 1, No. 2, pp. 44-49, 2018.

[8] F.A. Lubis, D. Isynuwardhana and V. Juliana, "Pengaruh Loan to Deposit Ratio (LDR), Non Performing Loan (NPL), Capital Adequacy Ratio (CAR), Net Interest Margin (NIM), Biaya Operasional Pendapatan Operasional (BOPO) Terhadap Return on Asset (Studi Kasus pada Perusahaan Perbankan yang Terdaftar di Bursa Efek Indonesia Tahun 2012-2015)," e-Proceeding of Management, Vol. 4, No. 3, pp. 25752584, 2017.

[9] Taswan, Manajemen Perbankan, Konsep, Teori dan Aplikasi. Yogyakarta: UPP AMP YKPN, 2010.

[10] Z. Ally, "Determinants of Banks' Profitability in a Developing Economy: Empirical Evidence from Tanzania," European Journal of Business and Management, Vol. 6, No. 31, pp. 2222-2839, 2014.

[11] P.K. Ozili, "Determinants of Bank Profitability and Basel Capital Regulation: Empirical Evidence from Nigeria," Research Journal of Finance and Accounting, Vol. 6, No. 2, pp. 124-131, 2015.

[12] E. Menicucci and G. Paolucci, "The determinants of bank profitability: empirical evidence from European banking sector," Journal of Financial Reporting and Accounting, Vol. 14, No. 1, pp. 86-115, 2016.
[13] A. Roman and A.C. Sargu, "Analysing the Financial Soundness of the Commercial Banks in Romania: An Approach based on the Camels Framework'," Procedia Economics and Finance, Vol. 6, No. 13, pp. 703-712, 2013

[14] A. Samad, "Determinants Bank Profitability: Empirical Evidence from Bangladesh Commercial Banks," International Journal of Financial Research, Vol. 6, No. 3, pp. 173-179, 2015.

[15] Q. Haidary and B. Abbey, "Financial Performance of Commercial Banks in Afghanistan," International Journal of Economics and Financial Issues, Vol. 8, No. 1, pp. 242-249, 2018

[16] H. Ramlan and M. Bin Nodin, "the Effect Leverage , Liquidity and Profitability on the Companies Performance," Journal of Humanities, Language, Culture and Business (HLCB), Vol. 2, No. 7, pp. 9-15, 2018.

[17] Ikatan Bankir Indonesia, Manajemen Kesehatan Bank Berbasis Risiko. Jakarta: Gramedia Pustaka Utama, 2016

[18] S. Yuksel and S. Zengin, "Influencing Factors of Net Interest Margin in Turkish Banking Sector," International Journal of Economics and Financial Issues, Vol. 7, No. 1, pp. 178-191, 2017.

[19] M. Nyarko-Baasi, "Effects of Non-Performing Loans on the Profitability of Commercial Banks - A Study of Some Selected Banks on the Ghana Stock Exchange," Global Journal of Management and Business Research: C Finance, Vol. 18, No. 2, 2018.

[20] I. Fahmi, Manajemen Perbankan: Konvensional dan Syariah. Jakarta: Mitra Wacana Media, 2015.

[21] N.G. Mankiw, Macroeconomics. Ninth Edition. New York: Worth Publishers, 2016.

[22] S. Juwita, P. Dewa, J. Raga, F.I. Prasetyo and E. Rimawan, "Effect of CAR (Capital Adequacy Ratio), BOPO (Operational Costs on Operational Revenues) and LDR (Loan to Deposit Ratio) to ROA (Return on Assets) PD Bank Pasar Bogor City," International Journal of Innovative Science and Research Technology, Vol. 3, No. 6, pp. 305309, 2018.

[23] D. Kusmayadi, "Analysis of Effect of Capital Adequacy Ratio, Loan to Deposit Ratio, Non Performing Loan, Bopo, and Size on Return on Assets in Rural Banks at Indonesia," Saudi Journal of Business and Management Studies (SJBMS), 6663, 2018.

[24] S. Ndoka and M. Islami, "The Impact of Credit Risk Management in the Profitability of Albanian Commercial Banks During the Period 20052015," European Journal of Sustainable Development, Vol. 5, No. 3, pp. 445-452, 2016.

[25] M. Bilal, A. Saeed, A.A. Gull, and T. Akram, "Influence of Bank Specific and Macroeconomic Factors on Profitability of Commercial Banks: A Case Study of Pakistan," Research Journal of Finance and Accounting, Vol. 4, No. 2, 2013 